\title{
Poesia ao grau de brinquedo: uma leitura de Manoel de Barros
}

Poetry as a toy: a study of Manoel de Barros

Rafaela Moreira Rodrigues UFF 


\section{Resumo}

Este artigo propõe uma leitura crítica da poesia de Manoel de Barros - com ênfase nos poemas presentes no livro Memórias Inventadas. As Infâncias de Manoel de Barros tendo em vista a preocupação com o exercício poético presente na obra. $\mathrm{Na}$ verdade, verifica-se a existência de um jogo dinâmico caracterizado por uma poesia que se quer reflexiva, ao passo que evoca a materialidade feita "brinquedo". As metapoesias, frequentes nessa obra, deixam claro que o desejo do poeta é alcançar algo que é anterior à palavra e, portanto, pretende se situar no princípio do que se pode dizer, por isso, é recorrente o uso de referências como a criança, os pássaros e/ou os andarilhos. Essa situação primitiva/primordial parece ser a fronteira entre perceber o mundo e as coisas e conceituá-los. Isto é, entre a percepção sensorial e a organização do sentido dessas coisas em linguagem, acontece uma "travessia", um deslocamento de uma condição para outra. Diante disso, foi possível indagar de que maneira a poesia se realiza como brinquedo e arte de brincar pelo "trans-uso" da linguagem, ou seja, pensar as relações entre brinquedo e poesia observando a possibilidade de serem instrumentos que viabilizam o deslocamento entre significantes e significados.

Palavras-chave: Manoel de Barros; Poesia; Infância; Brinquedo

\section{Abstract}

This research proposes a critical reading of the poetry of Manoel de Barros - with emphasis on the poems in the book Memórias Inventadas. As Infâncias de Manoel de Barros in view of the preoccupation with the poetic exercise present in his work. In fact, there is a dynamic game characterized by a poetry that wants to be reflexive while evoking the materiality made "toy". The metapoetry, frequent in this work, make it clear that the poet's desire is to achieve something that is prior to the word and therefore intends to place himself on the principle of what can be said, so it is recurrent to use references such as the child, the birds and/or the wanderers. This primitive/primordial situation seems to be the frontier between perceiving the world and things and conceptualizing them. That is, between the sensory perception and the organization of the meaning of these things in language, a "crossing" happens, a displacement from one condition to another. In view of this, it was possible to inquire how poetry performs as a toy and art of playing through the "trans-use" of language, that is, to think of the relations between toy and poetry, observing the possibility of being instruments that enable the displacement between signifiers and meanings.

Keywords: Manoel de Barros; poetry; childhood; toy 
Sentia mais prazer de brincar com as palavras do que de pensar com elas. Dispensava pensar.

Aprendera no Circo, bá idos, que a palavra tem que chegar ao grau de brinquedo Para ser séria de rir. Manoel de Barros

A leitura do livro Memórias Inventadas. As Infâncias de Manoel de Barros e a percepção sobre o que o poeta declara a respeito de seu ofício de escritor fizeram amadurecer a ideia de pensar essa poesia a partir das referências trazidas por ela mesma, bem como por meio das poucas explicações que o próprio poeta deu a respeito do seu fazer poético: "As primeiras percepções do mundo a criança que tem, quando nasce. E essas primeiras percepções são usadas por mim, na minha poesia. E completadas com o conhecimento que adquiri através das leituras do mundo."

Memórias Inventadas tinha, como proposta inicial, a publicação de três livros que reunissem poemas falando a respeito de três fases da vida do poeta: infância, adolescência e maturidade. O primeiro, Memórias Inventadas: A Infância, foi publicado em 2004, e os livros seguintes tiveram como subtítulo: $A$ segunda infância e $A$ terceira infância. Portanto, a infância não representa somente uma fase passageira da vida de cada indivíduo. Para essa poesia, a infância é "verbo", representa um espaço, um tempo, uma linguagem na qual se deseja permanecer. E se a temporalidade a afasta do poeta, ele a persegue até o último livro, "brincando" de versos.

O sentido que, nesses termos, "infância" assume se justifica em muitos momentos: na voz do poeta que afirma: "Eu só tive infância"2; no texto de apresentação do livro, intitulado Manoel por Manoel, que, ao contrário da edição estudada (a qual reúne as três infâncias num único volume), aparece como o primeiro texto das três edições anteriores, e que explica: "Acho que o que faço agora é o que não pude fazer na infância [...] Porque se a gente fala a partir de ser criança, a gente faz comunhão.”3; e em muitos dos metapoemas escritos por Manoel de Barros, nos quais se encontram versos como: "Poesia é a infância da língua."” ou "...quisera uma linguagem que obedecesse a desordem das falas infantis do que as ordens gramaticais."

O poeta Fabricio Carpinejar, em sua dissertação de mestrado: "Teologia do traste: A poesia do excesso de Manoel de Barros", também procura explicar a relação entre essa poesia e a infância:

1 BARROS, MANOEL DE. Poesia Completa, 2013, p. 467.

$2^{2}$ CEZAR, Pedro. Só dezpor cento é mentira. Desbiografia oficial do poeta Manoel de Barros, 2009.

3 BARROS, Manoel de. Memórias Inventadas. As Infâncias de Manoel de Barros, 2010, p. 187.

4 Idem. Poesia Completa, 2013, p. 7.

5 Ibidem, p. 113. 
Manoel de Barros não determina a finitude do ciclo de sua infância nem repassa a consciência de que terminou. Talvez porque a perceba como um espaço que pode ser frequentado toda hora, não um tempo que se esgotou. Sua postura é de tentar falar como se estivesse nela, não somente sobre ela 6 .

Se a percepção do poeta é a de que a infância não é um espaço-tempo esgotável e, por isso, ele pode acessá-la a qualquer momento, é interessante pensar de que modo isso é feito. Escrever como se estivesse nela é performatizar a infância. A performance, segundo Paul Zumthor (2000), é imprescindível para determinar o lugar, o tempo, a finalidade da transmissão do texto, a ação do locutor e, até mesmo, a resposta do público. É a performance que, além das regras estruturais de um texto, insere o leitor em um determinado contexto e amplia o seu alcance. Desse modo, deve-se cuidar para que o sentido estruturante de "infância" nessa obra não seja reduzido à tema.

Devido à recorrente visitação ao espaço-tempo da infância, a imagem da "criança" perpassa toda a obra de Manoel de Barros, por diversos motivos. Um motivo a ser ressaltado é o fato de a infância se apresentar como potência de voz, lugar passível de (re)construção linguística. As palavras não necessitam obedecer à prescrição gramatical e ultrapassam os limites semânticos e lexicais, constituindo novas estruturas e significações, diferentes das habituais. As crianças também são capazes de observar as coisas do mundo e a si mesmas, com o assombro e o encantamento da descoberta, o que amplifica a percepção e aflora os sentidos. Por se situar em um lugar do mundo sem mediação, quase um "não-lugar", em que se estabelece a fronteira entre língua e discurso, entre o "dizer" e o "não-dizer", entre a "voz" e o "silêncio", a infância apresenta-se como espaço de infinitas possibilidades.

A criança é capaz de estabelecer a comunhão com as coisas e não somente a comparação e a interpretação de tudo. Para elas, é mais fácil "transver o mundo"’ dom necessário para a poesia, segundo Manoel. Além disso, crianças possuem o hábito de brincar, são capazes de transformar qualquer objeto em brinquedo, bem como fazer de um brinquedo instrumento de infinitas possibilidades de brincadeira. A relação entre o brinquedo e a criança permite a analogia entre o poeta e a palavra. Ao escrever como uma criança e não sobre a infância, procedimentos próprios do mundo da criança são alçados à categoria de procedimentos de criação poética. E, nesse sentido, a poesia é brinquedo.

6 CARPINEJAR, F. Teologia do Traste: a poesia do excesso de Manoel de Barros, 2001, p. 25.

$7^{7}$ Expressão retirada do verso "É preciso transver o mundo", do poema "As Lições de R.Q.", publicado em: BARROS, Manoel de. Livro Sobre Nada, 1996. 
O conceito de "brinquedo" é a chave de leitura proposta neste artigo. Assim como as crianças fazem, desde os mais remotos tempos, o poeta "brinca" com os recursos que a natureza lhe oferece e com todos os tipos de objetos, os quais transformará, através da simples magia do jogo estabelecido com a palavra.

Michel Manson, no livro História do Brinquedo e dos Jogos - Brincar através dos tempos cita Aristófanes e, quando fala da relação que a criança mantém com o brinquedo, faz pensar sobre a relação que se estabelece entre Manoel de Barros e a poesia. “... tratase, simultaneamente, do desejo de possuir o objeto, da satisfação de ser ela (a criança) própria a fabricá-lo, conquanto de modo menos perfeito que um adulto, e, por fim, do prazer de jogar." 8

A fábrica de fazer poesia de Manoel parece não pretender ler um mundo preestabelecido por adultos, mas sim propor leituras sempre renovadas através do olhar de uma criança, que brinca. "Se (...) o brinquedo surge como um objeto sem nenhuma utilidade, o adulto reconhece contudo o desejo da criança de possuí-lo e a sua alegria quando os pais lhe oferecem um."”. É, nessa satisfação "infantil”, que o poeta se coloca na cena poética, trazendo à discussão, novamente, a questão da utilidade da poesia. Se, através dos tempos, os brinquedos foram considerados desde instrumentos pedagógicos fundamentais à educação até objetos inúteis, também a poesia foi e continua sendo pensada, por teorias literárias, sob ordens de utilidade e/ ou função.

\section{Infância e brinquedo}

Desde as primeiras publicações, Manoel de Barros traz, para a sua poesia, a fala de crianças: personagens como Paulina e o menino que não brincava com outros meninos porque era poeta (Poemas concebidos sem pecado, 1937), bem como João, seu filho, em que ele "pescava" poemas na fala (Compêndio para uso dos pássaros, 1960) e também o menino levado da breca (Memórias Inventadas, 2010).

Parece que tais personagens são capazes de aproximar o poeta do início, da origem, da autenticidade da palavra, uma vez que as crianças não estão preocupadas com dogmas ou ordenações impostas pela linguagem, podendo, assim, a poesia encontrar "a palavra arrombada a ponto de escombro"10, como pretendeu Manoel. O escombro é o resto, o que sobra após a destruição, portanto, abrir a palavra à força, a ponto de destroçá-la, é dar liberdade para que ela possa ser outra coisa e, principalmente,

8 MANSON, Michel. História dos brinquedos e dos jogos, 2002, p. 16.

9 Ibidem, p. 33.

10 BARROS, Manoel de. Memórias Inventadas. As Infâncias de Manoel de Barros, 2010, p.42. 
nada. É a partir do nada que algo inteiramente novo pode acontecer. "Uma nomeação inaugural é uma fala de criança." "11, afirma o poeta em entrevista. Portanto, Manoel de Barros, pratica a arte de "infantilizar o idioma", porque busca novos arranjos para a palavra, tensionando sentido e materialidade, experimentando, como uma criança que está, constantemente, (re)aprendendo.

Se, para fazer poesia, "o verbo tem que pegar delírio" 12 e se delirar é atingir um estado de exaltação, entusiasmo ou morbidez que faz com que se digam palavras sem nexo ${ }^{13}$ e, também, se "As coisas que não têm nome são mais pronunciadas/ por crianças" ${ }^{\prime \prime}$, parece que se trata de pensar a infância não simplesmente como o indizível, mas, principalmente, como uma "experiência transcendental" (expressão utilizada por Giorgio Agamben no primeiro capítulo livro Infância e História: destruição da experiência e origem da história) ao se referir a "...uma exposição da relação entre experiência e linguagem."15. Ou seja, na infância, “...os limites da linguagem não são buscados fora da linguagem, na direção de sua referência, mas em uma experiência da linguagem como tal, na sua pura autorreferencialidade" ${ }^{\prime 6}$. Dito de outro modo, Agamben sinaliza para a relação existente entre um sistema linguístico e as singularidades de um discurso, isto é, mais do que nomear, significa conceituar, pensar, experimentar. O filósofo questiona também como seria possível experimentar a linguagem desse modo e afirma que esse processo só é possível no momento em que o "nome" falta ao interlocutor, por isso sugere a infância apropriada para tal experiência linguística.

Fundamentalmente, mas não só, as metapoesias escritas por Manoel de Barros são bons exemplos de experimentação da linguagem em si mesma, como a metáfora: "escovar palavras", observada no poema "Escova". Tal ato possui o objetivo de encontrar os "clamores antigos" guardados nas palavras, para "escutar o primeiro esgar de cada uma." 17 . É com essa "Escova" que Manoel de Barros inicia suas Memórias Inventadas: inspirado nos arqueólogos que escovam ossos para estudar as pistas das civilizações anteriores. O eu poético afirma passar horas escovando as palavras, em busca do início de cada uma, antes da voz, anterior ao sentido determinado. $\mathrm{O}$ eu poético, em sua arqueologia, "escova" as palavras, consciente do que busca, mas "a turma" não entende:

11 Ibidem, p. 53.

12 Idem. Poesia Completa, 2013, p. 277.

$13^{13}$ Significado de "delírio", disponível em: https://www.dicio.com.br/delirio/, acessado em: 8 jun. 2017.

14 Ibidem, p. 276.

15 AGAMBEN, Giorgio. Infância e História: Destruição da experiência e origem da história. Belo Horizonte: UFMG, 2005, p. 12.

16 Ibidem.

17 BARROS, Manoel de. Memórias Inventadas. As Infâncias de Manoel de Barros, 2010, p. 15. 
...Passava horas

inteiras, dias inteiros fechado no quarto, trancado, a escovar palavras.

Logo a turma perguntou: o que eu fazia o dia inteiro trancado naquele quarto? Eu respondi a eles, meio entressonhado, que eu estava escovando palavras. Eles acharam que eu não batia bem. Então eu joguei a escova fora ${ }^{18}$.

Nesse poema, as crianças ("a turma") aparecem como a representação da "naturalidade", contrastando com a atitude inicialmente "mecânica" da criança-poeta a escovar, reconhecendo que a poesia é, também, um exercício. Jogar a escova fora pode ser admitir, além do trabalho especializado, um mundo múltiplo ao redor, que também precisa ser observado, vivenciado. E, nesse caso, é um mundo de crianças. $\mathrm{O}$ eu poético larga a escova para se juntar aos outros na brincadeira no quintal.

Para a criança, não há limite, o mundo inteiro é possibilidade, logo, infância é, também, potência de imaginação. Quando o poeta afirma: "Meu quintal é maior do que o mundo" ${ }^{19}$, acessa a imensidão resultante da combinação entre linguagem e imaginação. As palavras não são somente usadas para informar, são "trans-usadas" pelo poeta para compor silêncios, muito mais do que para "falar". O eu poético reconhece ser da "invencionática" 20 , então, a capacidade de imaginar também aparece diretamente ligada ao exercício de escrita.

Manoel de Barros retoma um verso presente em Livro Sobre Nada para a epígrafe de Memórias Inventadas: “Tudo que não invento é falso."21 Com isso, demonstra o quanto o processo de criação (no sentido de provocar a existência de algo) é protagonista nesse livro (e não só nele). O poeta proporciona a invenção, nesse verso, a mudança do seu status quo, conferindo-lhe valor de "verdade", bem como uma criança é capaz de acreditar ser verdadeiro um amigo imaginário, uma história que lhe foi contada ou uma situação inventada por ela mesma. "A imaginação é mais importante do que o saber."22. Desse modo, a poesia apresenta-se como "verdadeira" também por ser invenção, pois não se trata apenas de um jogo de palavras, mas sim de uma experiência, na qual infância e linguagem coexistem, não são uma a origem da outra, e não se consegue perceber o momento em que uma acaba e a outra começa. Giorgio Agamben pensa justamente as questões relacionadas a infância, linguagem, experiência e história e diz:

18 Ibidem.

19 Ibidem, p. 45.

20 Ibidem.

21 Ibidem, p. 7.

22 Ibidem, p. 183. 
...o próprio fato de que exista uma tal infância, de que exista, portanto, a experiência enquanto limite transcendental da linguagem, exclui que a linguagem possa ela mesma apresentar-se como totalidade e verdade. Se não houvesse a experiência, se não houvesse uma infância do homem, certamente a língua seria um 'jogo', cuja verdade coincidiria com o seu uso correto segundo regras lógico-gramaticais. Mas, a partir do momento em que existe uma experiência, que existe uma infância do homem, cuja expropriação é o sujeito da linguagem, a linguagem coloca-se então como o lugar em que a experiência deve tornar-se verdade. A instância da infância, como arqui-limite, na linguagem, manifesta-se, portanto, constituindo-a, como lugar da verdade ${ }^{23}$.

Agamben explica que a experiência da infância permite ao homem o silêncio e, por isso, confere-se à linguagem o lugar da "verdade", alcançada pela perspectiva e/ou percepção daquele que (não) diz. Ou seja, o homem, historicamente, não foi sempre "falante", os sistemas linguísticos não estavam postos antes do indivíduo, as experiências foram responsáveis por essas criações. O pensamento é anterior à nomenclatura e às regras. E é nesse sentido que o poeta afirma: "Só uso a palavra para compor meus silêncios." ${ }^{24}$. A linguagem é procurada, por Manoel de Barros, fora do cárcere de sentido e estrutura, em liberdade. O que se persegue é a experiência originária, anterior à linguagem, e esta mesma linguagem representa o limite demarcando o que está "antes do sujeito"25. Desse modo, parece ser a não-experiência linguística que possibilita, então, a expressão do inefável: "Era tão bela a frase porque irracional. Ele disse." 26.

Manoel de Barros reconstrói a língua, transformando-a, em busca de sentidos diferentes dos habituais, convidando às "ignorãças", "ao criançamento do idioma", porque, para ele, "só as palavras não foram castigadas com/a ordem natural das coisas. /As palavras continuam com seus deslimites."27 Estabelece-se profunda intimidade entre poesia e língua, a ponto de tornar possível a perversão, a reconstrução, o desvio e o desregramento que, a despeito da obediência sintática e/ou semântica, envolve e seduz. A língua parece ser um limite que precisa ser desconstruído em si mesmo. Ela é o instrumento fundamental de poesia, mas, ao mesmo tempo, sua imediatez e transparência decorrentes dos usos instituídos são, constantemente, negadas.

Isso acontece talvez porque, para ampliar a percepção de uma obra (como foi sugerido por Gumbrecht, pensando em consonância com Heidegger e o entendimento

23 AGAMBEN, Giorgio. Infância e História: Destruição da experiência e origem da história, 2005, p. 62. 24 BARROS, Manoel de. Memórias Inventadas. As Infâncias de Manoel de Barros, 2010, p.47.

25 AGAMBEN, Giorgio. Infância e História: Destruição da experiência e origem da história, 2005, p.58. 26 BARROS, Manoel de. Memórias Inventadas. As Infâncias de Manoel de Barros, 2010, p. 175.

27 Idem. Poesia Completa, 2013, p. 147. 
das obras de arte), seja necessário despir-se “da interpretação e da estruturação por meio de uma rede qualquer de conceitos histórica ou culturalmente específicos." ${ }^{28}$. Dito de outro modo, a percepção é particular, personalíssima. Se história e cultura são essenciais para a compreensão, é fundamental perceber a importância da dimensão experimental de uma obra, tanto de quem a produz quanto daquele que a recebe. O que quer dizer, grosso modo, que a infância, mais especificamente, a poesia, para Manoel de Barros, é possibilidade de "Ser-no-mundo", isto é, "recuperar a componente de presença em nossa relação com as coisas do mundo"29. Gumbrecht conceitua como "produção de presença" o efeito que uma obra evoca para além da sua significação preestabelecida. É nesse sentido, é na possibilidade da "experiência" que o "ser" se manifesta individualmente, presentifica-se no mundo, tarefa "infante". A reflexão do filósofo será melhor explorada adiante, articulando-a com ideia de "brinquedo verbal".

A poesia, nesse constante movimento de traição - em que necessita da língua e, concomitantemente, a perverte - é um lugar privilegiado para "Ser" plenamente, justamente porque permite a retirada quase completa do "Ser". E, no movimento de "retirada do Ser", a voz da poesia consegue aparecer. Escrever como poeta é atravessar caminhos em que coexistem o "belo" e o "imponderável”, e isso é um desafio, já que a demanda por uma comunicação que seja clara é uma regra social.

"Criar começa no desconhecer." ${ }^{30}$, afirma Manoel de Barros em entrevista. A imagem da criança é a do ser que desconhece, que ainda não está contaminado pelos conceitos existentes no mundo, e, portanto, mais apto ao contágio da poesia, um ato que se aproxima mais da esfera do sensível do que a de um estado mental. Em Memórias Inventadas, a infância é protagonista, justamente por representar uma espécie de "arquilimite" na linguagem, como foi observado por Agamben, e isso acontece desde que o poeta "concebia poemas sem pecado" 31 . A escolha do termo "pecado", longe de estar associada à ideia da violação de um preceito religioso, traz a noção da "pureza", expressa pelos sentidos (de significar e de sentir) da linguagem utilizada nessa poesia, que procura, quase obsessivamente, encontrar o pueril. "Buscar esse estado de inocência há de ser uma fuga. É também procura de essência. Busca de minadouros. Aventura humana atrás de natências." ${ }^{32}$. O poeta acredita que observar a criança e inscrever-se na infância como um espaço-lugar é uma estratégia potente de exercício poético, uma

28 GUMBRECHT, Hans Ulrich. Produção de Presença. O que o sentido não consegue transmitir, 2010, p. 95.

29 Ibidem, p. 92

30 BARROS, Manoel de. Memórias Inventadas. As Infâncias de Manoel de Barros, 2010, p. 159.

31 Referência ao primeiro livro publicado por Manoel de Barros: Poemas concebidos sem pecado, de 1937.

32 Idem. Memórias Inventadas. As Infâncias de Manoel de Barros, 2010, p. 145. 
vez que o aproxima do que para ele é essencial, o elemento fundamental, basilar dos poemas, o "início" da língua, a "despalavra" ’33. É curioso observar que o poeta afirma ser uma "fuga" em busca do estado de inocência da criança, caracterizando, mais uma vez, o movimento consciente de performance nessa poesia. Não é à toa que, desde o primeiro livro, os poemas dão voz às "crianças-personagens" e à criança que o poeta procura não perder de si.

O poeta traz à cena eus poéticos que descobrem, na infância, o ofício de escritor, bem como crianças que brincam de palavras e de inventar brinquedos (e um mundo inteiro), a partir do seu quintal. Nessas infâncias fabricadas, objetos transformam-se em coisas que não estavam destinadas a ser, trasmudando a sua identidade, e crianças se aproximam do meio natural, tanto da beleza e do bucolismo da natureza quanto de seus dejetos, misturando esses elementos, transformando-os em instrumentos de brincar. O poeta apropria-se desse contexto para dizer que a poesia está em todo lugar e pode ser, principalmente, acessada quando se é "infância", pois, assim como salientou Octavio Paz, “... a criação poética é exercício da nossa liberdade, da nossa decisão de ser.” ${ }^{34}$. O poeta deseja ser a criança (ou o pássaro, ou o andarilho): “...quer ser outro, seu ser sempre o leva para além de si. E o homem perde o pé a cada instante, tomba a cada passo e esbarra nesse outro que imagina ser e que lhe escapa das mãos." ${ }^{\text {"35 }}$, e se desculpa em versos como: "Perdoai./ Mas eu preciso ser outros./Eu penso renovar o homem usando borboletas." ${ }^{36}$ Essa renovação parece acontecer na própria linguagem, na voz poética que tanto é o outro quanto ele mesmo.

Muitas são as crianças que escrevem o poeta Manoel de Barros, desde a criança que passa horas sentada na escrivaninha escovando palavras, até a que tenta pegar a bunda do vento. E todas essas crianças são responsáveis por representar uma espécie de poética da infância. Pensar em uma "poética da infância" não é, de modo algum, afirmar que essa é uma poesia infantil, pelo contrário, é procurar demonstrar que essa é uma experiência de poesia tal qual a experiência da infância pensada por Agamben e já mencionada: "Como infância do homem, a experiência é a simples diferença entre humano e linguístico. Que o homem não seja sempre já falante, que ele tenha sido e seja ainda in-fante, isto é, a experiência." ${ }^{37}$.

33 Termo utilizado na parte 16 do poema "Retrato do Artista Quando Coisa". Idem. Poesia Completa, 2013, p. 341.

34 PAZ, Octavio. O arco e a lira. São Paulo: Cosac Naify, 2012, p. 186.

35 Ibidem, p. 187.

36 BARROS, MANOEL DE. Poesia Completa, 2013, p. 348.

37 AGAMBEN, Giorgio. Infância e História: Destruição da experiência e origem da história, 2005, p. 62. 
Quando o poeta procura se aproximar ao máximo de uma instância nãolinguística parece pretender "...escutar o silêncio das paredes." ${ }^{38}$, ou renovar a poesia com palavras ainda não ditas, ou já ditas, porém rearranjadas sintática e semanticamente. O período de aquisição da linguagem por uma criança parece ilustrar a relação entre poeta e palavra, a transposição do limite do não-dizer para o dizer é similar a um canto, à palavra inicial e, portanto, não permeada ainda de conceitos prévios que induzem a determinado uso. Por isso, a criança é, muitas vezes, retomada nesses poemas e, observar e reinventar a sua fala, apresenta-se como uma das estratégias adotadas na poesia de Manoel. O poeta reconhece a importância disso para o processo de escrita:

\footnotetext{
Acho saudável o poeta partir do inominável, da primeira fala engrolada, dos mistérios iniciais com que a ignorância nos brinda - partir desse ponto para a criação do poema. Então, reaprender a errar a língua seria encostar-se de novo nos germínios da fala. Começar do início da voz. E esse privilégio de chegar no início da voz, ao seu primeiro balbucio, - esse é privilégio dos poetas $^{39}$.
}

Especificar que se tem a intenção de "encostar-se nos germínios da fala" é colocar a oralidade em destaque na concepção dessa poesia. Isso é interessante porque se trata de uma poesia escrita. O poeta escreve poesia e, ao fazê-lo, se insere no paradigma da tradição literária escrita. Desse modo, é perceptível uma relação de tensão entre a escrita, que tem suas próprias regras, e uma linguagem que remeta aos primórdios da fala e que, portanto, encerra uma dimensão oral-performática da língua. É no reconhecimento da fala da criança e da emergência do contexto cultural e situacional da infância e dessa "voz" na poesia de Manoel de Barros, que se identifica a natureza da performance, responsável por afetar o que é conhecido nesses poemas. Para Paul Zumthor, “...mesmo quando escrita, a linguagem era (é ainda, sem dúvida, para muitos) sentida como vocal..." ${ }^{\prime 0}$, e isso, quando se trata de poesia, é ainda mais latente, "...como se a poesia tivesse, entre os poderes da linguagem, a função de acusar o papel performativo desta..."41. Assim, parece que o próprio gênero "poesia" contribui para a estratégia que pretende Manoel de observar e reinventar a fala de crianças.

A infância não só auxilia o poeta a acessar o universo que guarda os "germínios" da palavra como também o coloca diante de um objeto constantemente utilizado por crianças: o brinquedo. Brinquedos, para as crianças, não são apenas os fabricados, com

38 BARROS, Manoel de. Memórias Inventadas. As Infâncias de Manoel de Barros, 2010, p. 27.

39 Ibidem, p. 80.

40 ZUMTHOR, Paul. Performance, Recepção, Leitura. São Paulo: EDUC, 2000, p.51-52.

41 Ibidem, p. 54. 
a função essencialmente prático-econômica, mas também, e principalmente, as coisas do mundo que não têm a funcionalidade direta de brinquedo e são consideradas, pelo senso comum, objetos "inúteis", restos, sucatas, dejetos etc. De acordo com o que foi verificado por Walter Benjamin, no ensaio Livros infantis antigos e esquecidos:

... as crianças têm um particular prazer em visitar oficinas onde se trabalha visivelmente com coisas. Elas se sentem atraídas irresistivelmente pelos detritos, onde quer que eles surjam - na construção de casas, na jardinagem, na carpintaria, na alfaiataria. Nesses detritos, elas reconhecem o rosto que o mundo das coisas assume para elas, e só para elas. Com tais detritos, não imitam o mundo dos adultos, mas colocam os restos e resíduos em uma relação nova e original. Assim, as próprias crianças constroem seu mundo de coisas, um microcosmo no macrocosmo ${ }^{42}$.

A citação de Benjamin faz pensar nos detritos como instrumentos auxiliares da imaginação da criança, os quais permitem criar um universo particular, daí ganharem dimensão de brinquedo. O que o filósofo sugere é a superação do equívoco histórico de que os brinquedos seriam unicamente miniaturas de um mundo adulto, uma interpretação completamente afastada da realidade infantil. Benjamin assinala para o protagonismo da criança em relação ao brinquedo. Não é o objeto que determinará a brincadeira, mas sim a criança, ao transformá-lo em instrumento de brincar. Essa transformação acontece graças ao poder de invenção das crianças. Desse modo, qualquer objeto do mundo pode alcançar o status de "brinquedo" na perspectiva infantil. Os "brinquedos", nesse sentido, não seriam responsáveis por representar um mundo que já existe, mas sim por ajudar na criação de um mundo próprio, cheio de sentidos novos, originais.

A análise benjaminiana da relação entre a criança e o brinquedo é análoga à leitura proposta neste artigo sobre a relação estabelecida entre o poeta e a poesia. $\mathrm{O}$ poeta incumbe-se de juntar fragmentos, pedacinhos de mundo [...] e desobjetos, revistos e reinventados por meio da escrita poética. Então, é interessante observar que, em grande parte desse processo, os objetos são representados como "brinquedos" nas mãos de crianças. É o caso do pente, "Desobjeto" visto no meio do quintal pelo menino que era esquerdo:

42 BENJAMIN, Walter. Magia e Técnica, Arte e Política. São Paulo: Brasiliense, 2012, p. 256-257. 
[...] o menino que era esquerdo

e tinha cacoete para poeta, justamente ele enxergara o pente naquele estado terminal. E o menino deu pra imaginar que o pente, naquele estado, já estaria incorporado à natureza como um rio, um osso, um lagarto. Eu acho que as árvores colaboravam na solidão daquele pente ${ }^{43}$.

O brinquedo verbal "pente" é "trans-visto" pelo poeta quando esquecido no meio do quintal, a ponto de deixar a sua funcionalidade porque “...já se havia incluído no chão que nem uma pedra um caramujo um sapo. Era uma coisa nova o pente." ${ }^{\prime 4}$. Essa "coisa nova" em que o objeto se transformou é representada nessa poesia através do olhar da criança, que imagina as coisas fora do sentido habitual, dando-lhes novas personalidades ou nenhuma. O pente perde sua condição de objeto manufaturado quando está "terminal", incorporado à natureza como o rio ou o osso ou o lagarto. Indiferencia-se da natureza, pois a sua morte lhe confere situação orgânica para também se tornar vestígio, rastro, talvez achado arqueológico. Essa indiferenciação aponta também para uma visão de mundo que não se detém nas categorizações estabelecidas pelo conhecimento humano. Portanto, não é somente o "brinquedo" que representará a brincadeira, é o olhar da criança que tratará disso, assim como não são as palavras as determinantes da poesia, mas sim o seu “trans-uso" por parte do poeta. É uma experiência, e isso não exclui a significação, mas a ultrapassa.

Manoel de Barros fala também sobre uma infância diferente da contemporânea, em que não se tinha acesso a brinquedos fabricados e, por isso, as crianças fabricavam seus próprios brinquedos com sucatas:

\footnotetext{
Isto porque a gente foi criada em lugar onde não tinha brinquedo fabricado. Isto porque a gente havia que fabricar os nossos brinquedos: eram boizinhos de osso, bolas de meia, automóveis de lata. Também a gente fazia de conta que sapo é boi de cela e viajava de sapo. Outra era ouvir nas conchas as origens do mundo. $[\ldots]^{45}$.
}

O verbo fabricar é mais frequentemente associado à ideia de transformação de matérias-primas em produtos para o mercado, fato que se distancia um pouco do que é fazer poesia. Escrever poesia, ao que parece, tem mais a ver com um processo inventivo, semelhante ao da criança que cria seus brinquedos. $O$ fato de as crianças "fabricarem" os brinquedos com elementos naturais demonstra uma ironia sutil e

43 BARROS, Manoel de. Memórias Inventadas. As Infâncias de Manoel de Barros, 2010, p. 23.

44 Ibidem.

45 Ibidem, p. 71. 
inversa à ideia suscitada pela expressão "viajar de sapo" pois, para "viajar de sapo", não se precisa mais do que a imaginação. Também é a capacidade de imaginar que faz a aproximação entre poeta e criança, brinquedo e palavra, brincadeira e poesia.

Observa-se, nesse fragmento de poema, que a concha também é brinquedo de criança e, ao aproximá-la do ouvido, permite que se escute “as origens do mundo”. Essa imagem retoma a do poema "Escova", em que o eu poético é criança, "arqueólogo da palavra”, e a escova até escutar os clamores antigos. Tais clamores, seriam uma espécie de "antesmente verbal" ou "despalavra mesmo"46 e a criança que aproxima a concha do ouvido remete, novamente, à noção da não-linguagem, que muito diz ao poeta e que ele encontra, na infância.

Brinquedo de poeta é, então, a palavra. Para Agamben, o brinquedo é o melhor representante da temporalidade histórica, até mesmo superando os monumentos históricos e artísticos, uma vez que, ele diz: “O brinquedo é uma materialização da historicidade contida nos objetos, que ele consegue extrair por meio de uma manipulação particular." 47 .

A mutabilidade do brinquedo e a sua historicidade, a capacidade de ser e de não ser mais a qualquer tempo, outra coisa, ou nenhuma, tal como informou Agamben, são características semelhantes à da escrita poética visto que, assim como a criança e o brinquedo, o poeta “...serve-se de fragmentos e de peças pertencentes a outros conjuntos estruturais (ou, em todo caso, de conjuntos estruturais modificados), [...] transforma assim antigos significados em significantes e vice-versa." ${ }^{\prime 4}$.

É a partir da percepção de que brinquedo e palavra possuem um caráter mutável, são objetos passíveis de desestabilizações provocadas por crianças, ou por poetas, que se adentra, então, no terreno da brincadeira e do jogo poético.

\section{Brincadeira e Invenção}

Manoel de Barros declarou, certa vez: "Inventei meus brinquedos e meu vocabulário." 49 e essa afirmativa parece explicar, resumidamente, a sua "biografia poética". Trata-se de uma "brincadeira" apre(e)ndida na infância: a criança treinou o olhar do poeta de hoje: “...eu trago das minhas raízes crianceiras a visão comungante

46 Referência a trechos do poema 16 do livro Retrato de Artista Quando Coisa, de 1998. In: BARROS, MANOEL DE. Poesia Completa, 2013, p. 329.

47 AGAMBEN, Giorgio. Infância e História: Destruição da experiência e origem da história, 2005, p. 86. 48 Ibidem, p. 87.

49 BARROS, Manoel de. Encontros, 2010, p. 40. 
e oblíqua das coisas." ${ }^{50}$; a criança que cresceu no mato, isolada ${ }^{51}$ ensinou o poeta a imaginar: "Acho que isso me obrigava a ampliar o meu mundo com o imaginário." 52 ; a criança que não possuía brinquedos fabricados, ensinou o poeta a criá-los e a brincar: "Tive que fazer eu mesmo as artices da infância" 53 .

É importante ressaltar que na brincadeira do poeta a linguagem possui notoriedade:

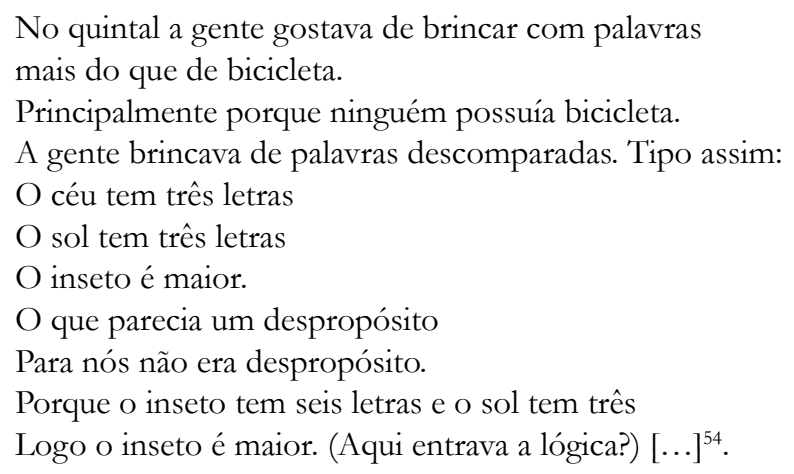

O poema destacado, "Brincadeiras", apresenta um eu poético narrador de uma memória, em que a brincadeira era "descomparar" as palavras. Talvez, "comparar" fosse algo da ordem semântica do léxico, fato não expresso aqui, visto que, o jogo acontece com o número de letras das palavras e não os seus significados. De acordo com o poema, as crianças preferiam brincar assim, mesmo porque, precisavam inventar brincadeiras, pois não possuíam brinquedos fabricados. Revela-se uma brincadeira que acontece de acordo com a estrutura do brinquedo-palavra, a despeito da sua significação.

Como se vê, a brincadeira de poeta está muito associada ao aspecto estrutural da língua, porém, além disso, a significação e a invenção também entram no jogo de poesia. É importante sinalizar que, em todos os âmbitos, a linguagem será brinquedo de demolição, ou seja, a língua é utilizada pelo poeta a favor da reconstrução de regras e conceitos previstos anteriormente:

Ao poeta penso que cabe a função de arejar as palavras. E não deixar que morram de clichês. Pegar as mais espolegadas, as mais prostituídas pelos lugares-comuns e lhe dar novas sintaxes, novas companhias. Colocar, por

50 Idem. Memórias Inventadas. As Infâncias de Manoel de Barros, 2010, p. 187.

51 Idem. Encontros, 2010, p. 40.

52 Ibidem.

53 Ibidem.

54 Idem. Memórias Inventadas. As Infâncias de Manoel de Barros, 2010, p. 51. 
exemplo, ao lado de uma palavra solene um pedaço de esterco. O poeta precisa de reaprender a errar a língua. Esse exercício poderá também nos devolver a inocência da fala. Se for para tirar gosto poético é bom perverter a linguagem. Temos de molecar o idioma, os idiomas. O nosso paladar de ler anda com tédio. É preciso injetar nos verbos insanidades, para que eles transmitam aos nomes os seus delírios ${ }^{55}$.

Manoel de Barros acredita ser função do poeta o arejamento do idioma, ou seja, destituir a palavra do senso comum, corromper a prescrição da gramática, desestabilizar as estruturas e propor novos arranjos. "Reaprender a errar a língua" é um caminho para "devolver a inocência da fala", e isso é motivo insistente dessa poesia. A "brincadeira" é o argumento que tanto desresponsabiliza o poeta por cumprir as rígidas regras gramaticais, quanto lhe permite acessar a imaginação livremente e inventar sem compromisso com determinadas verdades. "Brincando" as crianças não precisam atender o princípio da lógica. Logo, se o poeta afirma que está a brincar, a delirar, ele está informando que é preciso se desprender um pouco dos significados e conceitos já conhecidos sobre as coisas para se conectar a essa poesia.

Para o poeta, poesia não precisa dar informação: “A voz da poesia tem que chegar ao nada para aparecer. Só fui reconhecido quando não tinha mais nada pra dizer - e fiquei a brincar." ${ }^{56}$. Parece ser justamente quando as palavras são combinadas a partir de uma sintaxe inexistente, ou quando a oralidade é transcrita para a poesia, e até mesmo quando ocorre um desvio semântico, que acontece o “jogo”, a brincadeira, porém, mesmo quando brincadeira, o jogo poético revela determinadas estratégias.

Mesmo assim, a brincadeira afasta-se da seriedade do trabalho, da rigidez segundo a qual tudo deve estar organizado conforme regras bem definidas, e aproxima-se da liberdade. Tal liberdade dá ao poeta e, consequentemente, ao poema, o afastamento da realidade que é fundamentalmente, uma forma de expressão poética, pois a natureza da poesia situa-se na esfera lúdica, como foi observado por Johan Huizinga no livro Homo Ludens:

\footnotetext{
... a função do poeta continua situada na esfera lúdica em que nasceu. E, na realidade, a poiesis é uma função lúdica. Ela se exerce no interior da função lúdica do espírito, num mundo próprio para ela criado pelo espírito, o qual as coisas possuem uma fisionomia inteiramente diferente da que apresentam na "vida comum", e estão ligadas por relações diferentes das da lógica e da causalidade. Se a seriedade só pudesse ser concebida nos termos da vida real, a poesia jamais poderia elevar-se ao nível da seriedade. Ela está para além da seriedade, naquele plano mais primitivo e originário a que pertencem a criança, o animal, o selvagem e o visionário, na região
}

55 Idem. Encontros, 2010, p. 54.

56 Ibidem, p. 100. 
do sonho, do encantamento, do êxtase e do riso. Para compreender a poesia precisamos ser capazes de envergar a alma da criança como se fosse uma capa mágica, e admitir a superioridade da sabedoria infantil sobre a do adulto ${ }^{57}$.

É no Livro Sobre Nada que Manoel de Barros vai falar pela primeira vez, em poesia, que: "Palavra poética tem que chegar ao grau de brinquedo para ser séria." Em 2007, amplia a ideia em Poeminha em Lingua de Brincar. “... a palavra tem/ que chegar ao grau de brinquedo/ Para ser séria de rir" ${ }^{\prime 59}$. Nesses brinquedos-verbais, o poeta confirma o que foi observado por Huinzinga, a seriedade poética tem a ver com o lúdico, com o jogo, com o prazer. Ao brincar de designar as coisas, o poeta oscila entre a matéria e o pensamento, inventa expressões abstratas e essa atitude representa um jogo de palavras. Nesse jogo, um novo mundo é criado, denominado por Huinzinga "mundo poético".

A criação do mundo poético só é possível através da invenção, da imaginação. Para Manoel, "A invenção serve para aumentar o mundo" ${ }^{60}$, daí a necessidade de ampliar o mundo para a poesia, como o poeta admite, inventando versos: "Tenho uma confissão: noventa por cento do que/escrevo é invenção, só dez por cento é mentira." ${ }^{61}$. Também no âmbito da invenção a criança é fértil, porque tem, na brincadeira, infinitas possibilidades de criar:

\footnotetext{
Naquele dia, no meio do jantar, eu contei que tentara pegar na bunda do vento - mas o rabo do vento escorregava muito e eu não consegui pegar. Eu teria sete anos. A mãe fez um sorriso carinhoso para mim e não disse nada. Meus irmãos deram gaitadas me gozando. O pai ficou preocupado e disse que eu tivera um vareio de imaginação ${ }^{62}$.
}

O início do poema "Soberania", destacado acima e presente em "A Terceira Infância", ilustra a associação entre a brincadeira da criança e a invenção. Quando o menino tenta "pegar a bunda do vento" sem sucesso, parece que a brincadeira típica de uma infância livre, em que se pode correr a favor ou contra os ventos, é transposta em palavras. Essas palavras criam, tanto o mundo da criança quanto o mundo da

57 HUIZINGA, Johan. Homo ludens, 2014, p. 133.

58 BARROS, MANOEL DE. Poesia Completa, 2013, p. 322.

59 Ibidem, p. 467.

60 Declaração transcrita da fala de Manoel de Barros no documentário Só dez por cento é mentira.

61 Ibidem, p. 361.

62 Ibidem, p. 183. 
poesia, o imaginário. Para os adultos, a imaginação é um delírio, um "vareio" (o que é curioso, pois se a imaginação é atualmente associada ao irreal, na antiguidade, era vista como intermediária do conhecimento e se acreditava que o homem não poderia conceber absolutamente nada sem ela), tanto que, ao longo do poema o pai afirma: “...esses vareios acabariam com os estudos" ${ }^{63}$ e manda o menino estudar em livros. Depois de muito ler e conhecer teóricos, filósofos e eruditos, o menino encontrou uma frase de Einstein que dizia: "A imaginação é mais importante que o saber." elevada, sublime. A partir disso, ele declara: "E fiz uma brincadeira. Botei/um pouco de inocência na erudição. Deu certo. Meu/ olho começou a ver de novo as pobres coisas do chão mijadas de orvalho.”. A inocência infantil é responsável pelo olhar para "as pobres coisas de chão", tanto porque a ingenuidade de criança e o seu caráter pueril ajudam na percepção das coisas "desimportantes", ou "menores”, segundo o senso comum; quanto porque a baixa estatura das crianças as coloca muito mais próximas das coisas pequenas do mundo do que dos elementos de um universo adulto.

Manifesta-se, novamente, a ideia da brincadeira de palavras, da importância de manter a inocência do olhar para perceber as coisas do mundo e transformá-las em poesia. As coisas não necessitam de "soberania" para serem poesia, o desimportante, o ínfimo, é o que importa de fato, como borboletas que não precisam de motores para voar ou pousar nas flores e nas pedras sem risco de destruição. Para obter essa compreensão é necessário imaginar, daí a sabedoria infantil, para a criança não há limite, tudo é possível, até mesmo "pegar o rabo do vento".

A relação da criança com o brinquedo (bem como a relação do homem com os objetos) estaria na origem da criação artística porque expressa “...um misto de alegria impenetrável e de frustração estupefata..." ${ }^{\prime 65}$. Portanto, não é necessário que o objeto seja precisamente um brinquedo (coisa fabricada com a finalidade ou utilidade de brinquedo), porque, no geral, os indivíduos relacionam-se com os objetos do mundo mesclando prazer e insatisfação, um jogo dinâmico em que oscilam tese e antítese, e a partir do qual a "invenção" é possível.

Quando Manoel de Barros escreve o verso: "Inventei um menino levado da breca para me ser" ${ }^{66}$ no poema "Invenção", ele parece reafirmar a língua como o "brinquedo" de poeta, bem como a performatização da criança como estratégia de escrita. É através do menino que busca os objetos do chão porque não gostava de “...

63 Ibidem.

64 Ibidem.

65 BENJAMIN, Walter. Magia e Técnica, Arte e Política, 2012, p. 96.

66 BARROS, Manoel de. Memórias Inventadas. As Infâncias de Manoel de Barros, 2010, p. 151. 
obedecer a arrumação das coisas." ${ }^{67}$, que o poeta acessa o espaço de potência da poesia. A regra da brincadeira e da invenção permanece: desestabilizam-se as construções textuais normatizadas e se enfatiza a significação das palavras como algo suplementar, e não essencial para a poesia: "Aprendeu a dialogar com as águas ainda que não / soubesse nem as letras que uma palavra tem." ${ }^{68}$. A comunicação poética parece ser acontecimento para além de um conjunto de regras estabelecidas, o poeta persegue a comunhão entre os seres da natureza muito mais através do "sentir" do que do "sentido". É assim, também através da brincadeira e da invenção, que as crianças se relacionam com o mundo e as experiências.

Ao fim desse poema, a lógica da invenção se inverte: se o eu poético afirmou ter inventado um menino levado da breca para sê-lo, esse mesmo menino, supostamente inventado por ele, o informa sobre o equívoco, afinal, foi o menino que inventou o poeta: "Porém o menino levado da breca ao fim me falou/ que ele não fora inventado por esse cara poeta/ Porque fui eu que inventei ele.".

"Brincar de poesia", portanto, é assumir para as palavras o "caráter essencial do brinquedo" observado por Agamben, isto é, se o brinquedo pode, de um uso a outro, ser qualquer coisa (ou nada), cabe ao poeta fazer as palavras "diferentes" (em significados e em arranjos linguísticos), melhor ainda quando isso ocorre de um verso para outro do mesmo poema, como acontece em "Invenção". Brincar e inventar parecem ser, então, estratégias correlatas de poesia.

Instituir o brinquedo como chave de leitura para a poesia é uma atitude corajosa do poeta, que se coloca contra a gravidade e a seriedade científica e evoca a experiência mais perto do natural possível (através da criança, dos pássaros, dos bugres etc.), para afirmar que "... a palavra tem/ que chegar a grau de brinquedo/ para ser séria de rir." ${ }^{69}$

O estágio de "brinquedo" pode ser alcançado através de uma formação de mato, de chão, de criança que possui o olhar treinado para o desimportante, para o que ainda não tem palavra poética que defina. Como traquinagem de menino, que fura a lona do circo para olhar as trapezistas nuas ${ }^{70}$ ou passa uma vida inteira "enfiando água no espeto"'71. A palavra é o brinquedo do poeta:

67 Ibidem.

68 Ibidem.

69 Idem. Poesia Completa, 2013, p. 467.

70 Referência ao poema “Circo”. Idem. Memórias Inventadas. As Infâncias de Manoel de Barros, 2010, p. 179.

71 Ibidem, p. 167. 
... podia

Se dizer que a gente estivesse pregado na vida

das palavras ao modo que lesma estivesse

pregada na existência de uma pedra. Foi no que

deu nossa formação. Voltamos ao homem das cavernas.

Ao canto inaugural. Pegamos na semente da voz.

Embicamos na metáfora. Agora a gente só sabe

Fazer desenhos verbais com imagens ${ }^{72}$.

Em seu primeiro canto, em liberdade, a palavra tem compromisso com a expressão do sentido que o poeta pretende criar, e não dos sentidos desgastados pelo uso. Desse modo, a palavra inaugural parece estar livre dos clichês. E, para que essa liberdade seja atingida, a relação entre homem e palavra precisa ser tão íntima quanto a da lesma com a pedra. A palavra é, assim, "trans-usada" na brincadeira de poesia.

A noção de "trans-uso" das palavras assemelha-se ao que Otávio Paz expressou a respeito da criação poética: um processo de descolamento das palavras do seu uso habitual para instituí-las em novos usos. Consiste em uma espécie de travessia no uso dos vocábulos, pensada a partir da perspectiva da palavra como brinquedo, o que supõe a materialidade e o sentido da linguagem. A poesia de Manoel de Barros mostrase inesgotável em seus significados, porque a linguagem é a própria "brincadeira" do poeta.

\section{Referências Bibliográficas}

AGAMBEN, Giorgio. Infância e História: Destruição da experiência e origem da história. Belo Horizonte: UFMG, 2005.

AGAMBEN, Giorgio. Mme. Panckoucke ou a fada do brinquedo. In: AGAMBEN, Giorgio. Estâncias: a palavra e o fantasma na cultura Ocidental. Belo Horizonte: UFMG, 2012.

BARROS, Manoel de. (Org. Adalberto Müller). Encontros. Rio de Janeiro: Beco do Azougue, 2010.

BARROS, Manoel de. Poesia Completa. São Paulo: LeYa, 2013.

BARROS, Manoel de. Memórias Inventadas. As infâncias de Manoel de Barros. São

72 Ibidem, p. 171. 
Paulo: Editora Planeta do Brasil, 2010.

BARROS, Manoel de. Gramática expositiva do chão: poesia quase toda. Rio de Janeiro:

Civilização Brasileira, 1990.

BENJAMIN, Walter. História Cultural do Brinquedo. In: BENJAMIN, Walter._Magia e Técnica, Arte e Política. São Paulo: Brasiliense, 2012.

BENJAMIN, Walter. Brinquedo e Brincadeira. In: BENJAMIN, Walter. Magia e Técnica, Arte e Política. São Paulo: Brasiliense, 2012.

CARPINEJAR, Fabrício. Teologia do Traste: a poesia do excesso de Manoel de Barros. Porto Alegre: UFRGS, 2001.

GUMBRECHT, Hans Ulrich. Produção de Presença. O que o sentido não consegue transmitir. Rio de Janeiro: Contraponto: PUC- Rio, 2010.

HUIZINGA, Johan. Homo ludens. São Paulo: Perspectiva, 2014.

MANSON, Michel. História dos brinquedos e dos jogos. Lisboa, Teorema, 2002.

MÜLLER, Adalberto. O avesso visivel. REVISTA USP, São Paulo, $\mathrm{n}^{\circ}$ 59, jun./ago., 2003.

PAZ, Octavio. O arco e a lira. São Paulo: Cosac Naify, 2012.

ROUSSEAU, Jean-Jacques. Do contrato social; Ensaio sobre a origem das linguas; Discurso sobre a origem e os fundamentos da desigualdade entre os homens. São Paulo: Nova Cultural, 1991.

ZUMTHOR, Paul. Performance, Recepção, Leitura. São Paulo: EDUC, 2000.

\section{Documentários:}

SÓ dez por cento é mentira. Desbiografia oficial do poeta Manoel de Barros. Direção de Pedro Cezar. Produção: Pedro Cezar, Katia Adler, Rafaela Treuffar, Lully Villar. Rio de Janeiro: Artesanato eletrônico, 2008. DVD (76 min.). 
LÍNGUA de Brincar. Direção: Lúcia Castello Branco e Gabriel Sanna. Co-Produção: Faculdade de Letras UFMG. Minas Gerais, 2006. DVD (80 min.).

Submissão: $12 / 05 / 2020$

Aceite: $24 / 07 / 2020$

https://doi.org/10.5007/2176-8552.2020.e72333

Esta obra foi licenciada com uma Licença Creative Commons Atribuição-NãoComercial 4.0 Internacional. 